\title{
An Analysis of The Halo Image Use on Non-Human Beings and Its Place in Art
}

\section{Hale İmgesinin İnsan Dışı Varlıklarda Kullanımı ve Sanattaki Yeri Üzerine Bir Analiz}

\section{Serdar Dartar}

Arş. Gör., Yıldız Teknik Üniversitesi, Sanat ve Tasarım Fakültesi, Sanat Bölümü, Bileşik Sanatlar Anasanat Dalı email: serdardartar@gmail.com (DORCID ID: https://orcid.org/0000-0002-5944-8331

\section{Lütfü Kaplanoğlu}

Doç. Dr., Yıldız Teknik Üniversitesi, Sanat ve Tasarım Fakültesi, Sanat Bölümü, Bileşik Sanatlar Anasanat Dalı email: 1kaplanoglu@gmail.com (DORCID ID: https://orcid.org/0000-0002-7094-8302

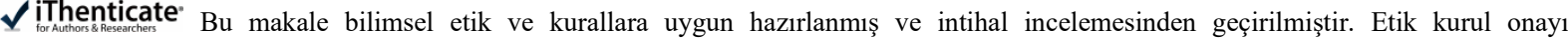 \\ gerektirmemektedir. \\ Atıf (APA 7)/To cite this article \\ Dartar, S., \& Kaplanoğlu, L. (2021). An analysis of the Halo image use on non-human beings and its place in art. Atatürk Üniversitesi Güzel \\ Sanatlar Enstitüsü Dergisi, 27(47), 520-531. https://doi.org/10.35247/ataunigsed.949990 \\ Makale Gönderim Tarihi/Received: 09/06/2021 \\ Makale Kabul Tarihi/Accepted: 30/09/2021 \\ Makale Yayun Tarihi/Published: 28/10/202
}

Review Article / Derleme Makale

$\ddot{O} z$

Sanat eserlerinde figürlerin kutsallı̆ıını ifade etmek amaciyla kafalarının etrafında veya vücudun bir bölümünde bulunan ya da vücudun tümünü sarmalayan ıșık halkalarına "hale" denir. Sanat eserleri örneklerinden yola çıkılarak M.Ö. 600'lü yıllara dayandırılan halelerin çıkıs yeri, büyük ihtimalle Asya'dır. Haleler, altın varak, sarı, kırmızı, mavi, yeşil, beyaz, siyah renklerde ve dairesel, üçgen, elips, kare formlarındadır. Zaman zaman iç içe geçmis daire biçimlerinde zaman zaman ates şeklinde betimlendikleri görülür. Kullanım şekilleri kültürlerarası farklılıklar gösterse de etkileșimden kaynaklı benzer kullanımlara da rastlanır. Haleler, Maniheizm, Budizm, Mecusilik, Tengricilik, Hristiyanlık, İslamiyet ve diğer din kültürlerinde yer alır. Pagan kültürden pekçok unsuru bünyesine katan Hıristiyanlıkta, ikonalarda, kutsal ruh, İsa, melekler, azizler ve dört İncil yazarı dișında dinin temsilcileri olan papaların, azizlerin ve kiliselerin koruyucularında görülür. Kutsallığın göstergesi olarak betimlenen halelerin hayvanlarda görülmesi sık rastlanılan bir durum değildir. Ama güvencin, kartal, boğa, aslan ve kuzu gibi bazı hayvanlarda da kullanıldığ görülür. Kutsal kișiler ve hayvanların haleli olarak bir arada kullanıldığına da rastlanır. Örneğin; Yunanistan, Bulgaristan, Rusya, Sirbistan ve Türkiye'de örnekleri bulunduğu üzere Aziz Christopher; köpek, at, eșek kafalı olarak haleli biçimde de temsil edilmiştir. Mısır sanatında betimlenen haleli hayvan figürleri, Hristiyanlıkta olduğu gibi kutsal niteliğini devam ettirmiştir. Türk sanatında ise haleli hayvan betimlemeleri, dindışı ve dekoratif özelliği ile diğer kültürlerden ayrılmaktadır. Haleler, sanat tarihinde sosyal, siyasal ve coğrafi şartlar içindeki serüvenini çeşitli biçimlerde sürdürmüştür. Çalışmada öncelikle halenin tarihsel süreci ve dinlere, kültürlere, coğrafyalara göre çeşitleri üzerinde durulmuş, konunun en önemli kısmı olan hayvanlarda görülen haleler hakkında bilgi verilmiş ve sanattaki yeri üzerine bir analiz yapılmıștır.

Anahtar kelimeler: Hale, Kutsallık, Minyatür, İkona, Sanat

\begin{abstract}
Light rings around the head or on a part of the body or surrounding the whole body used to express the holiness of figures in works of art are called "halo." Based on artwork samples, it can be stated that the origin of the halo image is most likely Asia, dating back to $600 \mathrm{BC}$. Sometimes they are depicted as fire and sometimes they are depicted as intertwined circles. Although their usage patterns differ among cultures, similar uses are also seen due to the interaction between cultures. In Christianity, which incorporates many elements from pagan culture, aside from the icons, the holy spirit, Jesus, angels, saints, and the four Gospel writers, they are also seen on popes, saints, and the protectors of churches, the representatives of the religion. It is not common to see haloes, used as signs of holiness, on animals. However, it is seen that they are also used on some animals such as doves, eagles, bulls, lions, and lambs. Animal figures with a halo, depicted in Egyptian art, continued to have a sacred quality in Christianity. In Turkish art, the animal depictions with halo differ from those in other cultures with their secular and decorative features. In this study, first, the historical process of the halo image and its varieties in different religions, cultures, and locations will be examined, information about the haloes seen on animals will be given, which is the most important part of the subject, and an analysis will be made on its place in art.
\end{abstract}

Keywords: Halo, Holiness, Sacredness, Miniature, İcon, Art

\section{Introduction}

Halo is a ring of light around the head, certain parts of the body, or the entire body indicating that a being is sacred, valuable, or extraordinary. In many ancient and monotheistic religions, especially in the religions with Tengri belief, haloes that are seen in paintings, sculptures, miniatures, mosaics, stained glass works, and sculptures, are used as an indication of holiness in belief systems associated with the sun, moon, and star clusters, based on the beliefs of light, fire, Tengri. Haloes, aside from prophets, apostles, priests, clergymen, and 
angels, are seen on heroes, artisan descriptions, depictions of sacred loves, and animals, which do not have religious quality according to cultures.

Even though haloes are generally dated back to the 2nd century BC, most of the sources state that they date back to around $570 \mathrm{BC}$ and their origin is Asia. The haloes depicted in gold leaf, yellow, red, blue, green, white, orange, and black colors take triangle, ellipse, square, circle shapes. Cultural images have spread to distant areas as a result of intercultural interactions for reasons such as migrations, wars, travels, religious expansion, and expeditions. It is seen that images that are accepted and adopted through these interactions may take place in similar or different ways in different cultures. Haloes have continued to exist in history of art from past to this day by being used in different social, political, and geographical environments throughout history.

\section{Method}

This research is a qualitative research based on descriptive model. Within the scope of the research, first of all, the historical process of the halo and its types according to religions, cultures and geographies were emphasized, information was given about the halos seen in animals and an analysis was made on its place in art.

\section{Results}

\subsection{The Historical Process of the Halo Image}

The origin of the halo symbol is related to the belief systems of light in all cultures, which are against darkness and accept the sun, moon, star clusters, and fire as sacred. According to Campbell (1992), haloes were first seen in Zoroastrianism in Persian art, as the ancient creation of Ahura Mazda, the god of brightness and light, was symbolized with the halo (570 BC), and they spread from there to the East, to Buddhism (563-483 BC) (Picture 1) and moved on to the West, to Christianity (s. 282). "Zoroastrianism symbolizes Ahura Mazda, the God of fire and light. Belief in fire has had a great impact on societies since ancient times and has been a symbol of purity and cleanliness." (Can, 2002, s. 169-179). This belief system has been spread to different geographical areas with the migration of the community who believed in Ahura Mazda. It went so far as to be "the official religious doctrine of Persian-Achaemenid (559-330 BC), Arsakid/Part (247 BC-224 AD), and Sassanid (224-652) empires established in Iran." (Alıc1, 2011, s. 549-578). "The traces of Shamanism, another religion with a belief in underground deity along with the solar system, can be seen in paintings from 13 to 15 thousand years BC" (İzgi, 2012, s. 3138). These traces continued to have an effect in Anatolia, but mainly in Central Asia. While traces of the Shamans, who are said to have migrated from Central Asia to Anatolia in $500 \mathrm{BC}$, can be seen, "In Sumerians, the Sky God is personified as An, and the Earth Goddess as Ki. Depending on their celestial bodies, the Sun God Utu and the Moon God Nanna stand out with their luminous features" (Hooke, 1993, s. 25).

The "Hittite Sun" symbol of the civilization established by the Hittites in Anatolia, the has a meaning for the Sumerian Civilization. The sun disk seen in Konya at Hittite Monuments demonstrates this importance. The Hittite Sun, which is an example of the haloes seen on the heads of Gods and Goddesses, has many types as a symbol and these halo symbols are also exhibited in the Museum of Anatolian Civilizations in Ankara. The haloes seen in the Hittite, Assyrian, and Akkadian figures have benefited from the religious figures of the same geography and all of them signal the sacredness of the sun. "Sumerian, Babylonian, and Assyrian kings who had a belief as expressed in the Myth of Etana with the words 'the kingdom is sent from heaven to earth,' claimed that the Gods chose and appointed them and acted as representatives of the Gods in rituals. In Egypt, the king is not a representative of God, but God himself" (Hooke, 1993, s. 68). So they have haloes on their own accord. But it is seen that the God King was later confused with the previous tradition, the cult of Sun God RA. It is seen that the cult of the Sun-God Ra has a much more important place in rituals and mythology in Egypt than in Sumerians and Akkadians. (Picture 2)

According to the historical tradition in Egypt, the Sun God RA is known as the creator of the world by the name of "Atum" as well as the first king of Egypt. As the name of Heliopolis (Solar City) indicates, it is the most important center of the cult of RA, and it is likely that the cult of Osiris and the cult of Sun God merged and united during the Old Kingdom period." (Hooke, 1993, s. 72). In addition to these, the Sun God is Helios in Greek mythology, Lugh in Celtic mythology, the Sun Goddess is Sol in Scandinavian Mythology, Ameterasu Goddess in Japanese mythology, Huitzilopochtli in Aztec mythology, and Kinich Ahau in the Mayans. The halo symbols in the representative figures of this Sun God belief in distant geographical locations are used with the same logic and form. 


\section{Picture 1}

Buddha with a Standing Halo-2nd Century AD

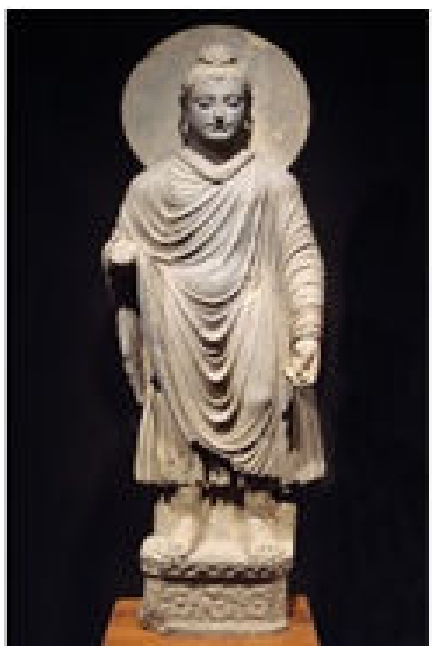

(World Imaging, 2004)

\section{Picture 2}

Ra with Sun Disc-Before 1235 BC

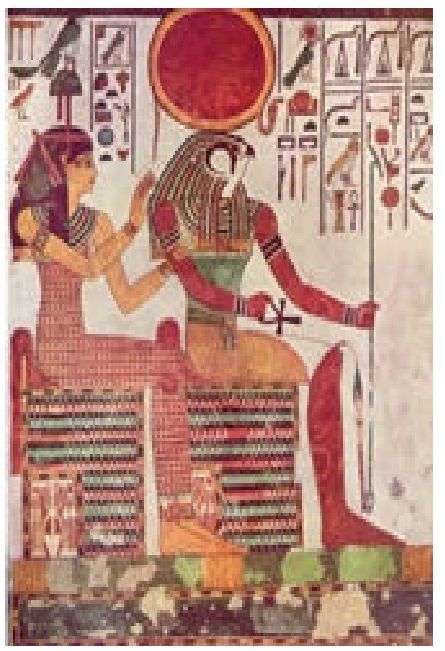

(Directmedia, 2002)

The first examples of artwork in Turkish art are the "Uyghur Miran paintings from 3rd century AD in East Turkistan. In these paintings, one of the paintings with haloes is seen in a portrait that has curves hanging from the cheeks, which is one of the striking features of Turkish painting. (Inal, 1995, s. 7). "The source of the circular halo seen in Turkish art is related to the belief system of Tengri, Mani and Shamanism, as well as the ruler or religious man in the Turks being regarded as holy and a member of the sky" (Çoruhlu, 1995, s. 577-580).

In the front page miniature of Kitab El Tiryak, it is interesting that there are haloes around the heads of many women and servants serving a ruler who is thought to be an Uyghur Turk. The fact that two women and two men in front of the ruler, the ruler, and four musicians on the left side are all depicted with a halo in al-Jazari's work "Automata," reveals a different aspect of halo in paintings in Uyghur.

In the stories in Hariri's "Makamat," the haloes seen in the miniatures of the adventures of two heroes and the middle play miniatures are given to these characters regardless of the religious characteristics of the persons. Also presented to Mahmut of Gazne, "Varka and Gülşah" constitutes a selection of 71 miniatures, which include important love stories, and rare works of divine love. In these artworks, haloes are seen on the heads of a local person who draws water from the well and the shopkeepers. Again in this mesnevi, "In the miniature showing Rabi's night raid, all seven people killed by Rabi have haloes, and in the work depicting the meeting of Rabi and Gülşah, the six figures in the farewell scene of Varka and Gülşah all have haloes, as well as Varka and Gülşah." (İnal, 1995, s. 52). These miniatures made with the theme of love are no different from the Roman, Anatolian, Persian, Buddhist, and Uyghur examples with their circular form of haloes. In the miniature of a sermon scene in 
the work of El Bruni (1307-1308), who lived in Anatolia during the Ilkhanians period, both the preacher and the people who listen to the preacher have a halo in the classical circular form. This shows that halo is not used as a symbol of holiness in all cultures, and has a different meaning in Turkish-Islamic miniatures. Halo is only a decorative element in Turkish miniatures.

\section{Picture 3}

Varka and Gülşah

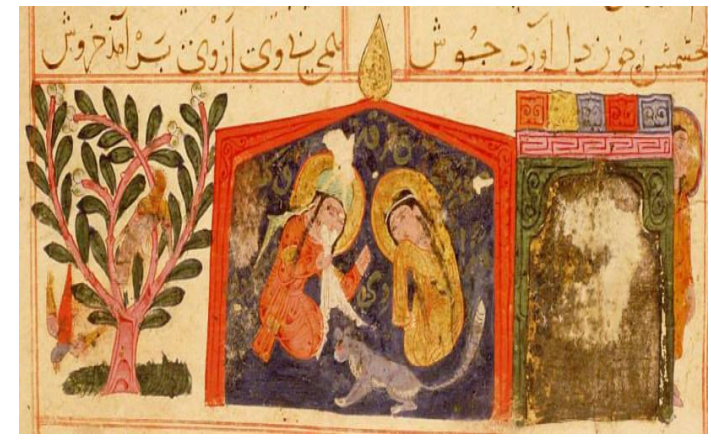

(Tasvir Sanatları, 2020)

The Khorasan Region, where the Great Seljuk State was present in the 11th-12th centuries, and the geographical location where the Anatolian Seljuk State (11-14th Century) was present is the starting point of civilizations. They had cultural interactions with Romans, their remains, in remote areas such as crusades, or with the miniature artworks in the painting school they established on the lands where Anatolian civilizations lived. It is seen that there were various themes during the Seljuk period. Especially a lot of animals with halos around their heads have reached our day with tile miniatures.

In the Ottoman Period, stories about the prophets are told in miniatures with figures that include the history of prophets such as Siyer-i Nebi (16th century) and Kisas-1 Anbiya. The miniature depiction in these stories are based on verses of the Qur'an and hadiths quoted from Mohammad's words. "In the verses of the Qur'an, because the moon is a star that reflects sunlight, fire-shaped haloes come from the sun, because and the sun is like a mirror that reflects God's essence, and the moon is like a mirror that reflects the light from the sun, Mohammed was representationally depicted as bright haloes (Çoruhlu, 1995, s. 577-680). The tradition of halo that had existed in Turkish art since the Uyghurs, ends after the miniatures of Siyer-i Nebi in Ottoman art. Although the Ottoman sultans were representatives of the religion, they were not depicted with a halo.

Halos are like a part of Roman mosaic because they are seen not in paintings but in mosaics in Hellenistic Greece and Rome. Poseidon is seen in the 2nd century Roman Tobian Mosaic and because he is sacred, Poseidon has a halo. However, there is no halo on Thritan and Neroid, who accompany him. After Apollo at the end of the 2nd century, haloes were also used for Alexander. Although this tradition continued after the Christianization of Rome, it mostly started to be seen on Jesus. (Picture 3) From this, it is understood that haloes existed before Christianity. "It is a general belief that haloes were seen in Christianity in the 6th century. According to this view, God appears in the early period as an iconic image of Jesus" (Campbell, 1994, s. 22). The haloes on these figures were only used to show God's light. Other views are that the halo is the logo of Jesus and that it came into being by itself. According to the Catholic belief, haloes representing the "Holy Spirit" are made in harmony with the whole body. While Orthodox argue that haloes existed in Jesus from birth, other Christian sects argue that they exist after baptism. Haloes are generally seen in the childhood period of Jesus. According to the Christian belief in the 6th century, while haloes are given to depict Jesus as sacred and to emphasize that he is a part of God, the haloes on the saints symbolize their consciousness and emphasize that the body is mortal.

In a text in which Jesus was greeted as the Messiah in an ancient Christian hymn written in 61-64 AD, it is expressed as follows: "He was the Messiah who, although in the Image of God, did not regard being equal to God as a merit, he took the image of a servant and he made himself like a human being, obeying in humility until death, even death at the cross" (Campbell, 1992, s. 280). The haloes, which reflect the holy spirit, represent the soul according to the Christian Catholic view and are harmoniously combined with the whole body. Eastern Orthodox see icons as the windows of heaven. Therefore, the haloes used in Orthodox icons are adopted as a window through which Christ and the saints in heaven can be seen. When the visuals in the history of art are examined, it is customary to use the halo, which is used to indicate the enlightened holy person in iconography, in the form of a ring.

The plain haloes in Christianity are meant to indicate the saints and were used by the Byzantine emperors for the prophets, angels, and four evangelists in the ancient sarcophagus. It is traditional to use the halo in a circular 
shape. There are also ones in the form of a triangle, square, and fire. In Christianity, triangle haloes are used to symbolize the Holy Spirit, the Father (God), and the Son (the Holy Trinity). In some paintings, the halo is depicted as God's hand coming out of the cloud. Papa Paschal has been depicted with a square halo throughout his life. It is understood that square haloes are for the supporters of the church and that the people depicted with square haloes are still alive. In Christianity culture, there are mandorla-shaped haloes that cover the entire body, cross-shaped haloes, star-shaped haloes, intertwined haloes, stars placed with regular interval among these intertwined haloes, striped haloes depicting light rays, haloes designed with symbols inside, light-shaped haloes, and cloud-shaped haloes (Picture 4)

In the haloes, which were used in white, yellow, and gold colors from Rome to Buddhism, and used in various colors in the first centuries of Christianity, the gold color became the standard later. Black haloes were used to indicate the devil. In 15th century Russian icons, Jesus is surrounded with a bright blue halo. The gold color in icons indicate heaven. Halo is the uncreated light or representation of God on the icon, his reflection. There are examples in gilded gold, transparent, white, yellow colors; in yellow-red-white color groups or with black contours with yellow or red inside. It is seen that the shape and color variety of the haloes differ according to the religious location and geographical conditions and the religions they are related to.

In terms of its shape, the halo is the focus of the composition in paintings and miniatures, so it is the focal point in terms of form. It softens the sharpness of the area and attracts the attention of the viewer with its classic circular form, especially in square and rectangular backgrounds. The infinity of the circular form is complementary to the semantics as the infinity principle brings spirituality, and in terms of form, it is softening the corners of the composition of the artwork.

Haloes are mirrors. It has structures that give God's light, sacredness, and feeling, and make the viewer feel his forgiveness and protection. European pictorial art had a great effect on the halo attracting more attention and becoming visible. There is an understanding that these images belong to Christianity in many cultures because of its value and place in European art in written and visual works. The emergence of this image before Christ and its existence until today and its spread to all over the world is important in terms of showing the power of cultural images before the 20th century, which is called the communication age. The halo image has completed its intercontinental travel without using today's communication tools and without getting caught in cultural, religious, and geographical barriers.

\subsection{The Use of Halo Image in Non-Human Beings}

The haloes that represent enlightenment in Buddha, the triumph of the light that prevails over darkness in Zoroastrianism, sacredness and power in Christianity are also seen on non-human beings. It is understood that the logic of using haloes seen in pictures representing the Christian religion, Egyptian paintings, and Turkish and Islamic miniatures is not the same.

In this triad, which is the Father, the Son, and the Holy Spirit according to the belief of God being the embodiment of three elements in the Trinity belief in Christianity, Jesus is meant by Son, while the Holy Spirit is represented by the dove. The Trinity belief has been depicted in various branches of Christian art for centuries with a number of images and symbols. When the tendency to portray people differently from each other increased in 15th century art, sometimes the Father and the Son were symbolized with similar figures, and the Holy Spirit with a dove. (Picture 4) It is not possible to characterize the dove as an animal in these halos. Because it has a special representation power.

The symbolization of the Holy Spirit in the form of a dove is mostly seen in the icon depictions of the Coronation of the Virgin Mary, but it has also been depicted as a young man. The best example of this can be seen in the tree sculpture group at Basilique Saint-Urbain de Troyes. The image of "Throne of Mercy" depicting the Trinity with symbols has been widespread throughout the Middle Ages. According to this image, the Father is depicted as an old man wearing the papal insignia, sits on the "Throne of Mercy," and holds the Son's body on the cross or descended from the cross. The dove hovers inbetween their heads." (Büyük Larousse, 1986, s. 11455) As Jesus was being baptized by John, the Holy Spirit descended from the sky in the shape of a dove. Christians would be guided by the Holy Spirit starting from the ascension of Jesus until the apocalypse. While the symbol of dove in Christianity is also seen in doves that represent the seven gifts of the Holy Spirit, the Holy Spirit in Michelangelo's painting depicting John's baptism of Jesus hovers over John and Jesus. On the shoulder of Jesus, who was baptized by John the Baptist, God lands on the shoulder of Jesus as a dove.

The symbol of Aphrodite, known as the Goddess of love and beauty in Greek mythology, is also a dove. According to the general belief, the dove is an innocent, pure bird, free from all kinds of sins. It is believed that the souls of sinless people who died take the form of a dove and fly over the earth.

In the 19th century Greek icon, which symbolizes the Pentecost holiday of the Descent of the Holy Spirit and depicts the descent of the Holy Spirit upon the Virgin Mary and the apostles during a dinner Fifty days after 
Easter, a beam of fire is seen on the dove (the Holy Spirit) and the head of the Virgin Mary. The flame-shaped haloes around this dove are similar to those seen in all cultures (Picture 4) (Y1lmaz, 1993, s. 153).

Like the stories of Mary, which take place in Islamic literature with the same logic, in "a Greek icon made in the 19th century of the archangel Gabriel heralding Mary that she will conceive" in the bible (Y1lmaz, 1993, s. 123), the white dove, symbolizing the Holy Spirit in the middle of the cloud cluster covering the area on the heads of the Virgin and the angel in half-round form, is witnessing this moment of good news.

In the depiction of the holy trinity according to the new testament in 19th century Greek icon, the Son Jesus is on the left, the Father God is sitting on the right, and the dove (the Holy Spirit) is hovering in an oval frame above with a red circular halo on a yellow orange background; the halo complements the holy trinity with its luminosity. (Y1lmaz, 1993, s. 173)

In the context of the same subject, artists of the Renaissance, Baroque $\backslash$ and later periods have made many similar artworks. The dove makes the audience feel its energy in paintings and icons with its luminous features.

\section{Picture 4}

Holy Spirit

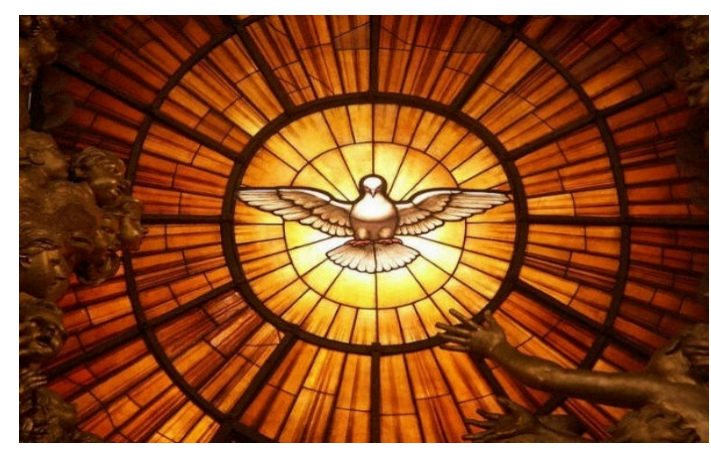

(Dnalor_01, 2003)

In Christianity, sheep is a symbol of Jesus. When John saw Jesus coming to him the next day, he said: "Behold, the Lamb of God that takes away the sin of the world!" (John 1:29, Incil, 2007). Lamb represents purity and innocence. In the role of the sacrificial, Jesus is personified: as the symbol of innocence, docility, kindness, humility, purity, and cleanliness, the lamb represents Jesus-Christ, sacrificed to pay for the sins of the world. Lamb and fish were used by oppressed Christians in the first centuries as codes (passwords) for recognizing each other. (Picture 5)

\section{Picture 5}

\section{Lamb of God}

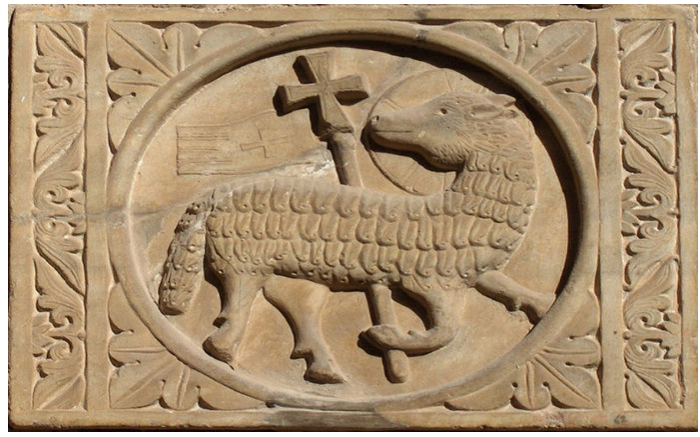

(Jansoone, 2007)

To discuss the eagle, the indispensable power symbol of many cultures, "In Egyptian and Iranian traditions, the Sun God is depicted as an eagle. Eagles are seen as symbols of luck and sacrificed to Zeus. The eagle is the symbol of Zeus in some cases, it symbolizes his power, intelligence, and sacredness" (Hançerlioğlu, 1975, s. 861). The eagles with a halo seen in the Christian paintings are also seen in mythological symbols as gods with half human and half animal appearance. The head of an eagle, depicted as human-body, eagle-head and seen in book illustrations, church walls and boards depicting the holy trinity, represents the power of St. John. St John is depicted as one of the four Evangelist Bible writers, the protector of the Bible, on many boards in Christian symbols. This depiction, seen in mosaics, carpets, graphics, and sculptures, also includes decorative features that began to appear after the early centuries (Picture 6). 


\section{Picture 6}

St. Eagle of Saint John

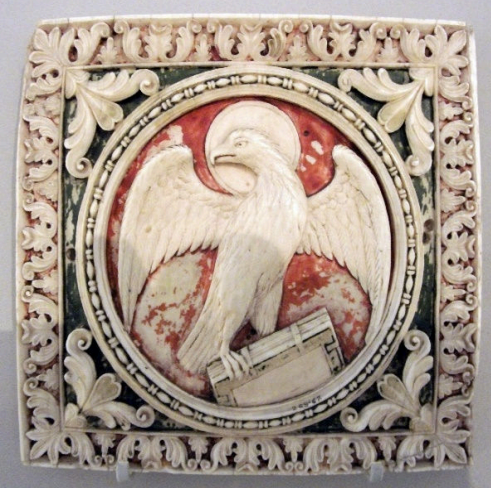

(Johnbod, 2010)

The bull represents Luke, one of the four biblical writers, in Christian representations. In Christianity each evangelist has a sign. The personal properties of these symbols may not be the same in all paintings. Luka has been depicted figuratively as a human figure by many artists in plain or with wings (Picture 7).

\section{Picture 7}

St Luke the Evangelist

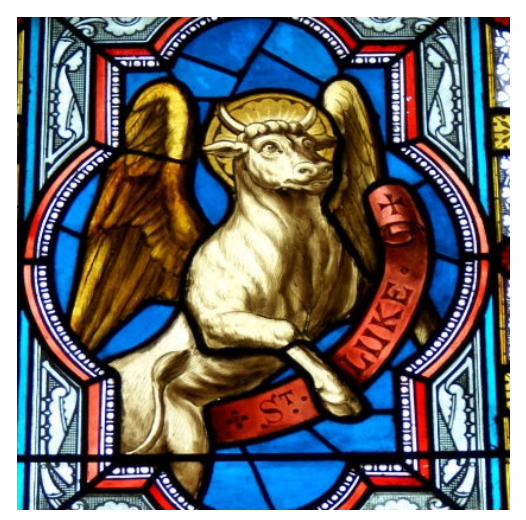

(Luke, t.y.)

The lion with a halo is the sign of St. Mark. Mark is one of the four evangelists and is depicted in paintings as a protective and spreader of the scriptures. The lion figure, which is used in many cultures due to its power, is widely seen in architecture. The haloes used on lions are depicted in their classical circular form. (Picture 8).

\section{Picture 8}

St Mark

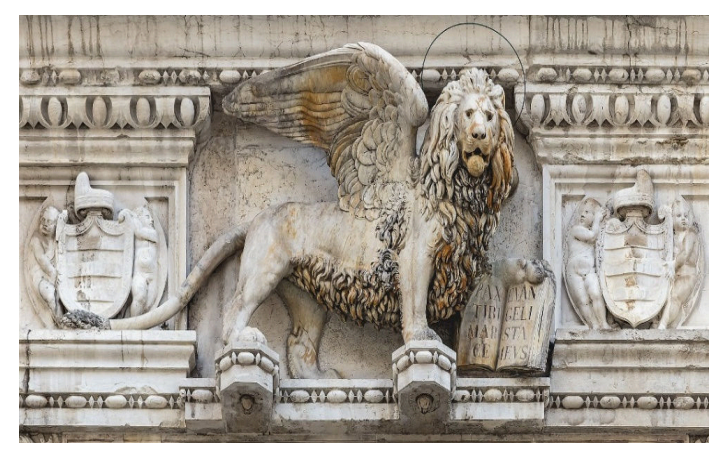

(Descounes, 2019)

The haloes are traditionally used in circular shape on the boards, where the lamb and the dove, that is, Jesus and the Holy Spirit are symbolized as the Thrinity with the hand of God. In fact, there are stained glass artworks in which Matthew, Mark, Luke, and John are depicted together. These images take place according to the characteristics and duties of each Evangelist in the scriptures. (Picture 9) 


\section{Picture 9}

Four Evangelists

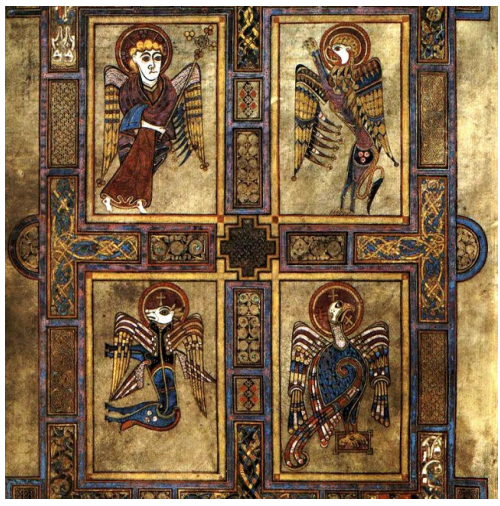

(Meehan, 2008)

There are different views in different sects of Christianity. These differences are those coming from the cultures they had before converting to Christianity, geographical differences, and differences of opinion, as in the Council of Nicaea. The difference in the icons of the Eastern Orthodox is that they are influenced by the geographical location as well as the classical icons. The best examples of this are seen in the East in animals such as dogs, donkeys, and horses that are close to human beings and are in their service, apart from sacred representations such as lions, eagles, doves, lambs, and bulls, which are known to exist in Europe. (Picture 9-10) This situation does not depreciate the person of their sacredness as a prototype even though it is the inner-outer image or a name attached to them. Their holiness and dignity continues and is accepted. For this reason, hundreds of examples can be found in the geography in which they exist as a cultural value. According to these stories from the myths of St. Christopher.

The saint was so handsome that he could not prevent women from advancing towards him and seducing him. Later he prayed to God to help him with this problem. God's solution was to give him a dog head, and the women immediately stopped seducing him. Other stories tell that he belongs to the dog-headed human race and speaks dog-headed language. (Ancient Faith Revealed, t.y.).

The icon of Saint Christopher was banned by the Synod in 1722 because it "contradicts nature, history, and the truth itself" due to the possibility of it causing doubt, anger, and surprise in believers (Chechko, 2019).

Hundreds of examples and depictions of dog-heads with haloes have been questioned in Egyptian connections. But the truth is the dog seen in Picture 10 means "exquisite" in Eastern philosophy and when it is tamed, the dog, the animal nature in the soul comes to an end. Regardless, it is an example of discipline on not leaving the door of God and not giving up serving the Lord until the purification is completed. Therefore, they are not different from the examples of Matthew, Mark, Luke, and John in terms of spirituality and holiness. The legend, the dog-headed Christopher is forgiven for taking the child Christ across the river and is depicted with the child Jesus on his shoulder. (Picture 10) Examples of these icons are found in Russia, Greece, Serbia, ÇengelköyTurkey, Bulgaria; in short, they are found in the East rather than Europe.

\section{Picture 10}

Dog Head Saint Christopher
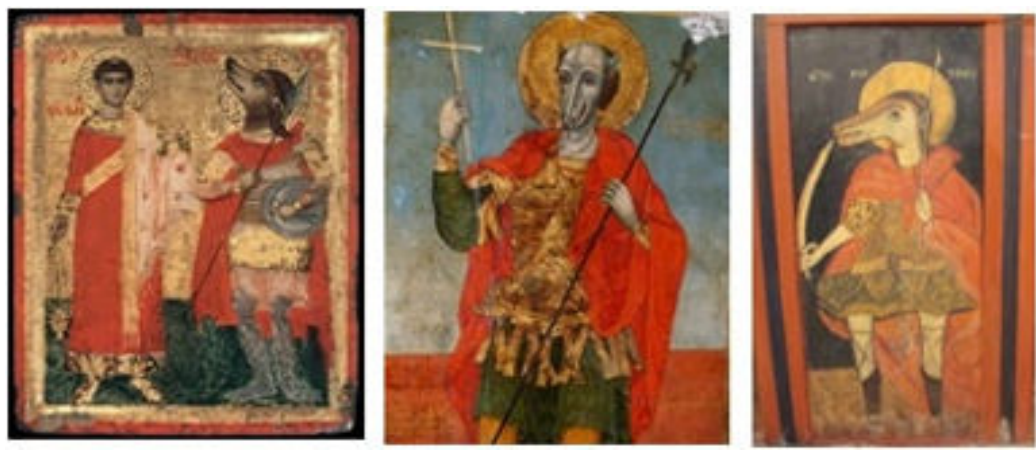

(Weebly, t.y.) 


\section{Picture 11}

Saint Christopher

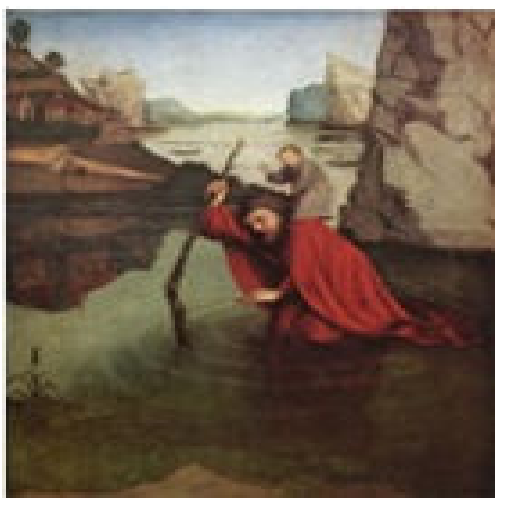

(Chechko, 2019)

The haloes that are used in depictions of animal Gods or to indicate God are the most widely known ones in Egypt. (Picture 12) Especially in Egypt, the halo is depicted as red and white disks because the halo was not acquired afterwards, it is not given to God by anyone, the halo is God according to the religion. These halos, which are seen on wolves, eagles, oxen, crocodiles, and lions, have black, blue, and yellow contours as symbols of power and might.

In Greek mythology, the transformation of Zeus, the God of Gods, into a bull in order to obtain Europe is seen in Asian, African, and Sumerians cultures; according to the Zoroastrian belief in ancient Persia, as the ox or bull created by Ahura Mazda, in Egypt it is a sign symbolic of gods of power and fertility. Because special temples are built and rituals are organized for specially selected ox known as Apis ox in Egypt. There are many varieties of figures with halo-headed animals seen in Egypt.

\section{Picture 12}

Animal Depictions of God with a Halo in Egypt
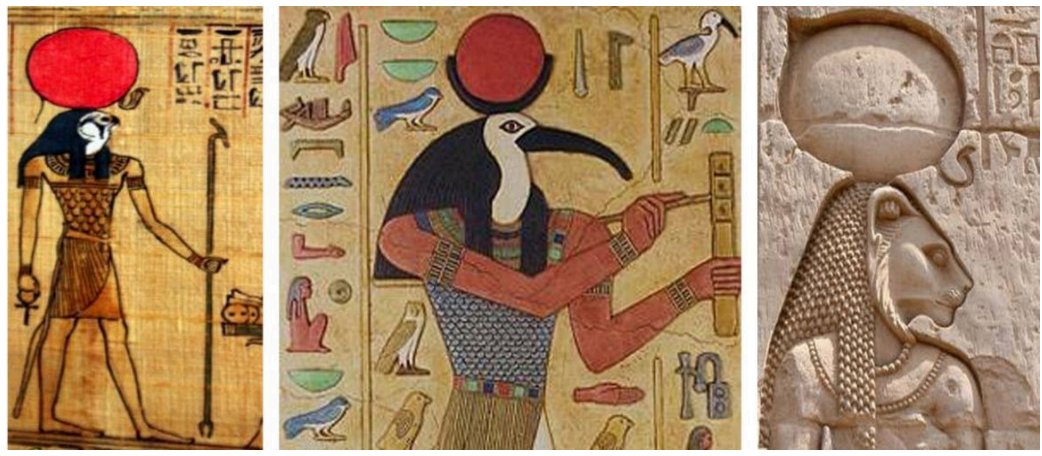

(Fwmail, t.y.)

It is not common to see haloes around the heads of animals. It is seen on the lion motifs on the tiles of the 11th century Seljuk Kubad-Abad Palace and in different birds in the paintings of the "Kelile and Dimme" story.

Kelile and Dimme, a story book written by Beydeba, who is thought to have lived around the 1st century BC, is a book that contains fables, and it is thought to have been written during the time of an Indian ruler named Depşelem. The symbol of "truth and honesty" is "Kelile," the symbol of "false and lies" is "Dimne" in the stories in Kelile and Dimne, which are among the first important examples of the fables genre ("Kelile ve Dimne", 2005).

Especially the crows draw attention in Kelile and Dimme. As the head vizier advises the crows, both he and the crows are depicted with a classical circular halo. (Picture 13) On another page of Kelile and Dimme, the crow is among four owls, while the halo is seen only on the crow. This description, which is handled with a decorative approach, has been left uncolored. It is seen that the share order in the color scheme of the composition draw attention because the crow is black. The crow is at a lower spatial level than the owls when meeting with the king of owls. The owls are depicted with horns. (Picture 13) There is no information that the crow is sacred in Turkish belief. It does not seem possible to make a connection in terms of the meaning of depiction with a halo. 


\section{Picture 13}

Crows with haloes in Kelile and Dimme
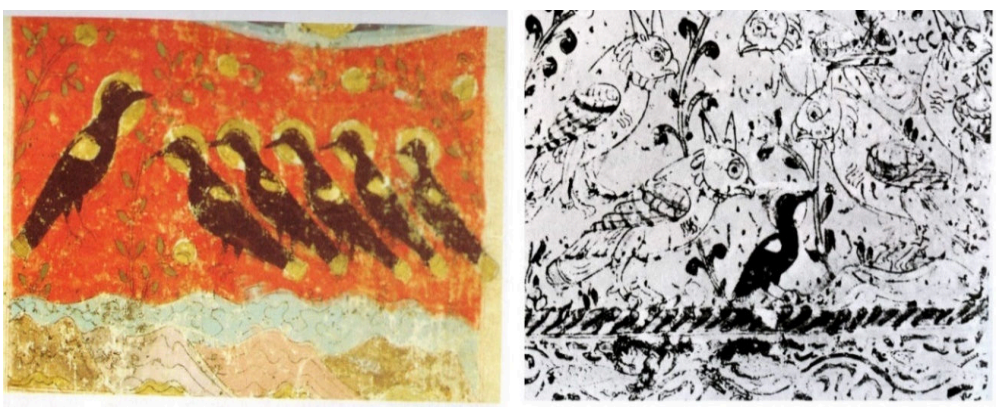

(Konak, 2014, s. 45)

Another bird with a halo featured in Kelile and Dimme is the owl. This composition, which is another version of the crow and owl painting seen in the black and white work, is about the crow's conversation with the king of owls. The king owl is positioned higher than the crow and four owls. The presence of the halo around the head of the owl, which does not have a religious connotation for Turks, is also interesting. (Picture 14)

Another bird with a halo featured in Kelile and Dimme is the doves. In addition to blue, yellow, and green colors, black contours were also used on doves painted on red background. (Picture 15) The presence of halo on the figure following the five doves in the composition supported with writing on the upper right of the work is thought to be used as a decorative element, or with the effect of a different cultural interactions of the period, regardless of holiness. Especially in Christianity, the dove, which is believed to be the soul of sinless people, is accepted as a symbol of love and peace due to its white color. It was believed in ancient Egypt that releasing doves would bring good news to the country and to the Gods.

\section{Picture 14}

Conversation of The Crow with The King of Owls

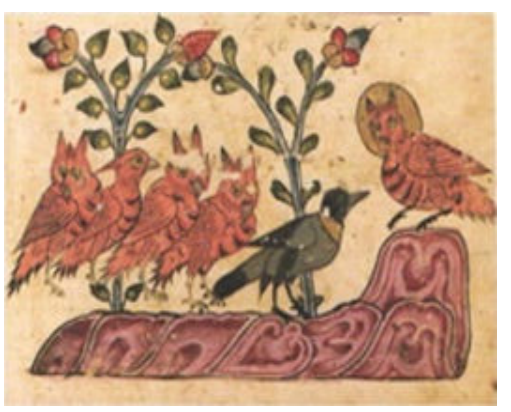

(Kizıldağ Atila, 2011, s. 37)

\section{Picture 15}

Doves with Haloes

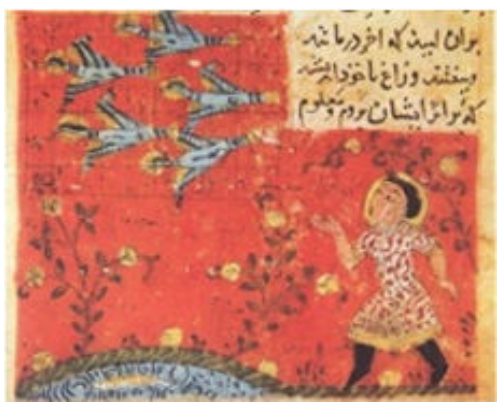

\section{(Areq, t.y.)}

The tiles at the Kubad Abad palace, one of the Seljuk period structures, present rich figure examples of Turkish tile art. The halos used on many figures, around the heads of figures with a lion/tiger body but human head, and around the head of figures with a bird body and human head, these figures coinciding with the period of Kelile and Dimme in the same century, reveals the characteristic of haloes being used by Turks or Seljuks. (Picture 16) 


\section{Pictures 16}

Examples of Animals with Halo in Kubad Abad Palace Tiles
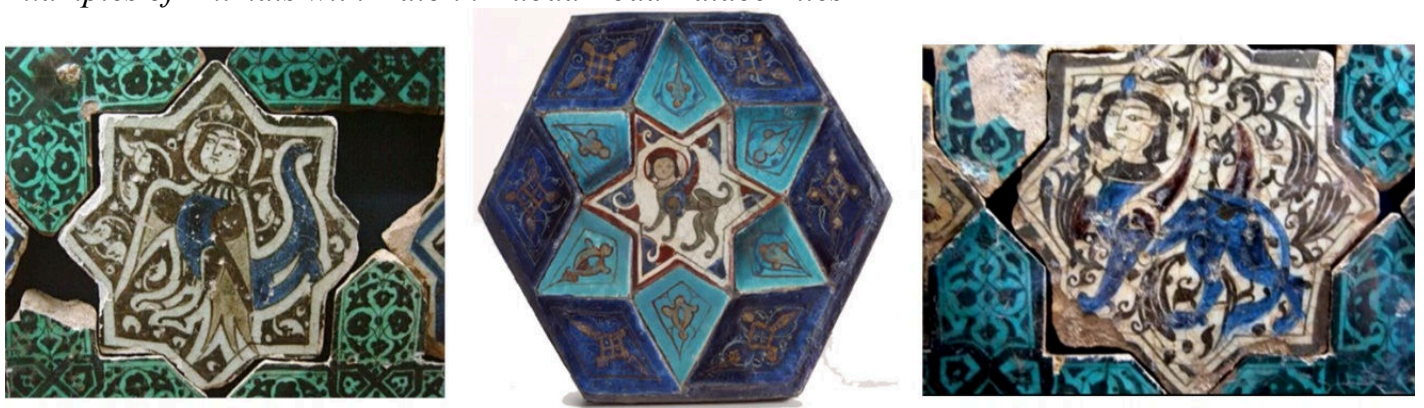

(Çetin, t.y.)

On these tiles decorating the Kubadabad palace, among the double-headed eagle, sphinx, wolf, lion, hawk, bear, lynx and many animal works like these, there are examples of haloes on figures with a bird body and human head or dog body and human head.

\section{Conclusion}

There are various types of haloes in almost all cultures in many colors; circle, triangle, and square haloes that date back to Persian miniatures or Asia, also depicted foggy and realistic fire. Even though their starting date cannot be identified with certainty, based on the fresco, miniature, and painting examples, the general conviction is that they date back to $600 \mathrm{BC}$, originating from Asia.

The continent of Asia has a very rich cultural background in terms of religious history. Seeing this variety of cultures as an "alliance of civilizations" and preserving these differences can be considered a common cultural responsibility, even if there are similarities and differences due to the relations of civilizations found in this rich culture. Whether Persian, Mesopotamia, Indian, Hittite, Seljuk, Ottoman, European, Christianity, Islam, Zoroastrian or the way of belief in the heavenly bodies, this image used as the light of the path of the sacred is a common cultural heritage.

The haloes seen in the Christian religious paintings of God, Jesus, Mary, and the apostles were traditionally present in European cultures before Christianity. Matthew, Mark, Luke, and John, the four Evangelists, are depicted as animals with a halo representing power, strength, innocence, purity, freedom, and peace as a representation of the Holy Spirit and Jesus. Horse-headed, donkey-headed, dog-headed depictions of Christopher with a halo were used in Orthodox Christians in Eastern Europe, especially in Bulgaria, Greece, Serbia, Turkey, and Russia, and Christopher was depicted with a halo and with child Jesus on his shoulder because he was forgiven after saving Jesus Christ from the river. The reason why animal depictions with a halo seen in Egypt are symbols of power is because the figures are already God himself.

The dove seen in Seljuk and Ottoman miniatures, which is the continuation of the crow and owl with halo examples seen in Miran paintings, the roots of Turkish painting art, was depicted with the same logic as a classical circle without any religious qualities. In Islamic art, fire-shaped haloes were generally depicted in golden color, although the sultans of the Ottoman Empire were the representatives of the religion (caliphs), they have no halo in any miniature. Animal depictions with halo used without the connotation of holiness, as in Seljuk tiles and "Kelile and Dimne" depictions, can be thought that circular haloes were used for decorative purposes on various bird, leopard, and dog-bodied human-head figures on tiles.

\section{References}

Alıcı, M. (2011). Genel Hatlarıyla Mecusilik ve Zerdüşt’ün Modern Takipçileri, Ortadoğu Yıllı̆̆ Ortadoğu Yıllı̆̆l.

Ancient Faith Revealed. (t.y.). Meet the dog-man. Discovering Eastern Orthodoxy. Retrieved January 4, 2021, from https://eastern-orthodox.weebly.com/meet-the-dog-man.html\#

Areq. (t.y.). Doves with haloes [Photograph]. https://areq.net $/ \mathrm{m} / \% \mathrm{D} 8 \% \mathrm{~A} 8 \% \mathrm{D} 9 \% 8 \mathrm{~A} \% \mathrm{D} 8 \% \mathrm{AA} \% \mathrm{D} 8 \% \mathrm{~A} 7 \%$ D9\%84\%D8\%AD \%D9\%83\%D9\%85\%D8\%A9.html

Büyük Larousse. (1986). Kutsal ruh. In Büyük Larousse Sözlük ve Ansiklopedisi. Gelişim Yayınları.

Campbell, J. (1992). Batı mitolojisi. (K. Emiroğlu, çev.) Ankara: : İmge Yayınları.

Campbell, J. (1994). Yaratıcı Mitoloji: Tanrının maskeleri. (K. Emiroğlu, çev.) Ankara: İmge Yayınları. 
Can, H. D. (2002). Hint Ateş Tanrısı Agni. Nüsha Şarkiyat Araştırmaları Dergisi, 2(7), s. 169-178.

Çetin, M. (t.y.). Examples of animals with halo in Kubad Abad Palace Tiles [Photograph]. https://tr.pinterest.com/bilanaciftci/sel\%C3\%A7uklu/

Chechko, D. (2019). Saint Christopher [Photograph]. https://blog.obitel-minsk.com/2019/08/a-beast-with-a-halowhat-do-we-know-of-the-most-arguable-saint.html

Chechko, D. (2019, August 14). A beast with a halo: What do we know of the most arguable saint? The Catalogue of Good Deeds. https://blog.obitel-minsk.com/2019/08/a-beast-with-a-halo-what-do-we-knowof-the most-arguable-saint.html

Çoruhlu, Y. (1995). Milletlerarası Türk Sanatları Kongresi. Ankara: Kültür Bakanlığı Yayınları.

Descounes, D. (2019). St Mark [Photograph]. https://en.wikipedia.org/wiki/Lion_of_Saint_Mark

Directmedia. (2002). Ra with Sun disc-Before 1235 BC [Photograph]. https://en.wikipedia.org/wiki/Halo (religious iconography)

Dnalor_01.(2003). Holy Spirit [Photograph]. https://en.wikipedia.org/wiki/Holy_Spirit

Fwmail.net. (t.y.). Animal depictions of God with a halo in Egypt [Photograph]. https://fwmail.net/genelkultur/antik-misir-tanrilari

Hançerlioğlu, O. (1975). Inanç Sözlüğü. İstanbul: Remzi Kitabevi.

Hooke, S. H. (1993). Ortadoğu Mitolojisi. (A. Şenel çev.) Ankara: İmge Yayınevi.

İnal, G. (1995). Minyatür Sanatı. Ankara: Atatürk Kültür Merkezi Yayınları.

Íncil. (2007). Kutsal Kitap. Yeni Yaşam Yayınları.

İzgi, M. C. (2012). Şamanizm ve Şamanlara genel bakış. Lokman Hekim Journal. 2(1), 31-38. https://dergipark. org.tr/tr/download/article-file/643357

Jansoone, G. (2007). Lamb of God [Photograph]. https://en.wikipedia.org/wiki/Lamb_of_God

Johnbod. (2010). St. Eagle of Saint John [Photograph].https://en.wikipedia.org/wiki/Eagle_of_Saint_John

Kelile ve Dimne. (2005, 6 Ekim). Wikipedia içinde. http://tr.wikipedia.org/wiki/Kelile_ve_Dimne

Kızıldağ Atila, O. (2011). Minyatür sanatındaki hayvan figürlerinin sembolik ifadeleri. Art Design, 1(2), 35-44. https://dergipark.org.tr/tr/download/article-file/1206

Konak, R. (2014). Minyatür sanatında boşluk ve mekân anlayışı, Akdeniz Sanat Dergisi, 7(14), 34-54. https://dergipark.org.tr/tr/download/article-file/275495

Luke. (t.y.). St Luke the Evangelist [Photograph]. https://anastpaul.com/2018/10/18/saint-of-the-day-18-octoberst-luke-the-evangelist/comment-page-1

Meehan, B. (2008). Four Evangelists [Photograph]. https://en.wikipedia.org/wiki/Four_Evangelists

Tasvir Sanatları. (2020). Varka and Gülşah [Photograph]. https://sirazduvari.com/varka-ile-gulsah-farsedebiyatinda-bir-ask-hikayesi/

Weebly. (t.y.). Dog Head Saint Christopher [Photograph]. https://eastern-orthodox.weebly.com/meet-the-dog$\underline{\text { man.html\# }}$

World Imaging. (2004). Buddha with as standing halo-2nd century AD [Photograph]. https://en.wikipedia.org/ wiki/Buddhist_art

Yılmaz, N. (1993). Ayasofya müzesindeki ikonalar kataloğu Cilt I-II. Kültür Bakanlı̆̆ı Yayınları. 